\title{
Volatility Spillovers Between Energy and Agricultural Markets in Theory and Practice
}

\author{
Chang, C.-L. ${ }^{1}$, Y. Li $^{2}$ and M. McAleer ${ }^{3}$ \\ ${ }^{I}$ Department of Applied Economics, Department of Finance, National Chung Hsing University, Taichung, \\ Taiwan \\ ${ }^{2}$ Department of Quantitative Finance, National Tsing Hua University, Taiwan \\ ${ }^{3}$ Department of Quantitative Finance, National Tsing Hua University, Taiwan, Econometric Institute, \\ Erasmus School of Economics, Erasmus University Rotterdam, Tinbergen Institute, The Netherlands, \\ Department of Quantitative Economics, Complutense University of Madrid, Spain
}

Email: michael.mcaleer@gmail.com

\begin{abstract}
Energy and agricultural commodities and markets have been examined extensively, albeit separately, for a number of years. In the energy literature, the returns, volatility and volatility spillovers (namely, the delayed effect of a returns shock in one asset on the subsequent volatility or covolatility in another asset), among alternative energy commodities, such as oil, gasoline and ethanol across different markets, have been analysed using a variety of univariate and multivariate models, estimation techniques, data sets, and time frequencies. A similar comment applies to the separate theoretical and empirical analysis of a wide range of agricultural commodities and markets. Given the recent interest and emphasis in bio-fuels and green energy, especially bio-ethanol, which is derived from a range of agricultural products, it is not surprising that there is a topical and developing literature on the spillovers between energy and agricultural markets. Modelling and testing spillovers between the energy and agricultural markets has typically been based on estimating multivariate conditional volatility models, specifically the BEKK and DCC models. The purpose of the paper is to evaluate the theory and practice in testing for volatility spillovers between energy and agricultural markets using the multivariate BEKK and DCC models, and to make recommendations as to how such spillovers might be tested using valid statistical techniques. Three new definitions of volatility and covolatility spillovers are given, and the different models used in empirical applications are evaluated in terms of the new definitions and statistical criteria.
\end{abstract}

Keywords: Energy and agricultural markets, volatility and covolatility spillovers, univariate and multivariate conditional volatility models, definitions of spillovers 


\section{INTRODUCTION}

Energy and agricultural commodities and markets have been examined extensively, albeit separately, for a number of years. In the energy literature, the returns, volatility and volatility spillovers (namely, the delayed effect of a returns shock in one financial asset on the subsequent volatility or covolatility in another asset), among alternative energy commodities, such as oil, gasoline and ethanol across different markets, have been analysed using a variety of univariate and multivariate models, estimation techniques, data sets, and time frequencies. A similar comment applies to the separate theoretical and empirical analysis of a wide range of agricultural commodities and markets. Given the recent interest and emphasis in bio-fuels and green energy, especially bio-ethanol, which can be derived from a range of agricultural products, it is not surprising that there is a topical and developing literature on the spillovers between energy and agricultural markets, where the emphasis is on testing the magnitude and direction of the volatility spillovers between alternative commodities in these markets.

The purpose of the paper is to evaluate the theory and practice in testing for volatility spillovers between energy and agricultural markets using the BEKK and DCC models, and to make recommendations as to how spillovers might be tested using valid statistical techniques.

\section{FULL AND PARTIAL VOLATILITY SPILLOVERS}

Volatility spillovers are defined as the delayed effect of a returns shock in one asset on the subsequent volatility or covolatility in another asset. Therefore, a model relating $Q_{t}$ to returns shocks is essential, and this will be addressed in the following sub-section. Spillovers can be defined in terms of full volatility spillovers and full covolatility spillovers, as well as partial covolatility spillovers, as follows, for $i, j, k=1, \ldots, m$ :

(1) Full volatility spillovers: $\partial Q_{i i t} / \partial \varepsilon_{k t-1}, k \neq i$;

(2) Full covolatility spillovers: $\partial Q_{i j t} / \partial \varepsilon_{k t-1}, i \neq j, k \neq i, j$;

(3) Partial covolatility spillovers: $\partial Q_{i j t} / \partial \varepsilon_{k t-1}, i \neq j, k=$ either $i$ or $j$.

Full volatility spillovers occur when the returns shock from financial asset $k$ affects the volatility of a different financial asset $i$. Full covolatility spillovers occur when the returns shock from financial asset $k$ affects the covolatility between two different financial assets, $i$ and $j$. Partial covolatility spillovers occur when the returns shock from financial asset $k$ affects the covolatility between two financial assets, $i$ and $j$, one of which can be asset $k$. When $m=2$, only (1) and (3) are possible as full covolatility spillovers depend on the existence of a third asset.

\section{CRITICAL ANALYSIS OF THE EMPIRICAL LITERATURE}

A useful analysis of the empirical literature on examining volatility spillovers has been presented in "The dynamic pattern of volatility spillovers between oil and agricultural markets" by Saucedo, Brümmer and Jaghdani (2015). The authors examined 23 published papers predominantly on the basis of univariate and multivariate conditional volatility models, as well as one paper on each of univariate stochastic volatility and univariate realized volatility. For this reason, in this paper we have chosen 11 of the 23 published empirical papers that have used the multivariate full BEKK model (in one paper, the diagonal BEKK model), and two papers that estimated both full BEKK and scalar DCC. Scalar BEKK was not used at all, and in some cases a univariate conditional model was presented in addition to its multivariate counterpart.

The 11 papers that will be appraised in chronological order are given in Tables 1A to 1C. The appraisal of the empirical literature in this section does not consider the empirical findings as these are already given in Saucedo, Brümmer and Jaghdani (2015), albeit not critically from either a mathematical or statistical perspective. In addition to the energy commodities, agricultural commodities, countries, multivariate conditional volatility models, sample periods, and data frequencies that were discussed in Saucedo, Brümmer and Jaghdani (2015), the paper also considers the journals in which the papers were published, the energy and agricultural prices (namely spot or futures prices), data sources, software packages used in estimation and testing, the univariate conditional volatility models used in estimation as a first step in estimating their multivariate counterparts, the types of spillover effects considered (namely full volatility, full covolatility and partial covolatility spillovers), the analytical and statistical properties of the conditional volatility models, the purported hypothesis tests, the purported statistical significance 
of the tests, and an overall assessment of each of the published papers. The 11 papers were published in some of the leading energy, agricultural and natural resource economics, and futures market journals, namely Energy Economics (3 papers), European Review of Agricultural Economics (2 papers), Energy Policy (2 papers), and one paper in each of the Journal of Agricultural and Resource Economics, Energy Journal, Energies, and Journal of Futures Markets.

Also given in Table 1A are the countries for which the energy and agricultural products data are obtained, predominantly the USA for ethanol, fuel ethanol, crude oil, light crude oil, heating oil, biodiesel, gasoline, and heating oil. Other countries or regions include France for ethanol, crude oil and biodiesel, European Union for oil, heating oil and gasoline, China for crude oil and fuel ethanol, international countries for crude oil and ethanol, and Brazil for crude oil and ethanol. Agricultural commodities include corn, rapeseed, soybeans, soybean oil, sugar and wheat for USA and France, barley, corn, sorghum and wheat for the USA and European Union, sugar for USA, Brazil and other international countries, and corn for USA and China.

Table 1A also shows that the most frequently used data on prices were for spot (or cash) prices (5 papers), futures prices (3 papers), and one paper each for both spot and futures prices, both spot prices and index, and nominal prices. The sample periods ranged from 1989, 1990, 1992, 1997, 2000, 2003, 2005-2006, and 2007-2013 for weekly data (7 papers), daily data (3 papers, and one paper that used monthly data for ethanol and corn (see also Table 1B)).

Table 1B also shows that the primary data sources included Bloomberg, EIA (energy, oil, crude oil, gasoline), IGC (cereal), CBOT (ethanol, corn, corn futures), FAO (corn), National Bureau of Statistics of China, Nebraska Government (ethanol), NASS (corn), CME (corn, ethanol, gasoline, light crude oil), NYMEX (gasoline, WTI, crude oil), CEPEA (ethanol, sugar), Center for Advanced Studies on Applied Economics (ethanol, sugar), USDA (corn cash), Ethanol and Biodiesel News (ethanol), and USDA (corn soybean).

The same table shows that only one paper stated the statistical, econometric or financial econometric software package, specifically, WinRATS version 6.30, that was used in estimation, whether for univariate or multivariate conditional volatility models. Consequently, there was no discussion of convergence of any algorithms that were used to estimate the models. This is a disappointing finding as it can be quite difficult to reproduce empirical results, especially for multivariate conditional volatility models, when the software package is not stated explicitly. Moreover, the "curse of dimensionality" cannot be determined when there is no discussion of the convergence of the algorithms, despite the fact it is well known that convergence is problematic when more than three financial assets are used to estimate the full BEKK model.

Table 1B provides some useful insights regarding the types of univariate and multivariate conditional volatility models that are estimated, as well as the alternative volatility spillovers that can be considered. Full BEKK is estimated in 7 papers, both full BEKK and scalar DCC are estimated in 2 papers, and diagonal BEKK and scalar DCC are each estimated separately in one paper. Full BEKK incorporates full volatility, full covolatility and partial co-volatility spillovers, while diagonal BEKK and scalar DCC allow only partial co-volatility spillovers.

As univariate models are necessary to obtain the standardized residuals for multivariate estimation, each of the papers uses at least one, indeed usually only one, univariate conditional volatility model to initiate the estimation process. Of the 11 published papers, 7 use only GARCH (including one semiparametric GARCH), 2 use threshold GARCH (also commonly known as GJR), one paper uses only EGARCH, and one uses both GARCH and EGARCH.

The analytical and statistical properties of the QMLE of the univariate and multivariate conditional volatility models are analysed in Table 1C. Somewhat surprisingly and disappointingly, all 11 papers ignore any discussion of the analytical properties of the multivariate conditional volatility models, and 9 of the papers also ignore the analytical properties of the univariate conditional volatility models as a precursor to estimating the multivariate models. Gardebroek and Hernandez (2014) report that $\alpha+\beta<1$, without explanation, but do not seem to appreciate that this is a sufficient but not necessary condition for the unconditional variance to be finite, and for the QMLE to be consistent. Wu and Li (2013) discuss the conditions for asymmetry and leverage for the EGARCH model, but do so incorrectly by concentrating on the first of two necessary conditions.

The papers purportedly test the hypotheses relating to volatility and covolatility spillovers without recognizing that such tests are invalid except for the diagonal and scalar BEKK models, and not valid 
whatsoever for scalar DCC. Only one paper fails to provide any evidence of any purported hypothesis tests or diagnostic checks, which include the standard Ljung-Box Q test for the absence of serial correlation in the residuals of the conditional mean equation (in 2 papers), normality tests of the returns shocks (in 4 papers), both unit root tests and cointegration tests (in 6 papers), tests of causality (in 3 papers), and a test for long memory (in one paper).

As can be seen from Table 1C, all 11 papers reported on the purported statistical significance of the estimated parameters, despite the fact that there is no proof that the statistical properties hold for diagnostic checks and statistical significance of estimated presence in the absence of asymptotic results for the multivariate conditional volatility models. These diagnostic checks are generally invalid in the presence of estimating volatility and covolatility spillovers, except under the null hypothesis that such spillovers do not exist, which would seem to destroy the primary purpose of the analysis. As 7 of the 11 papers used weekly data and one paper used monthly data, with the remaining 3 papers having used daily data, it is surprising that there were no tests conducted for seasonal unit roots or seasonal cointegration.

The last column in Table 1C makes it clear that the overall assessment of the empirical literature in estimating and testing for volatility and covolatility spillovers between the energy and agricultural markets is one of disappointment. In short, the theoretical and empirical analyses in every paper are questionable. The only tests that are valid asymptotically are for the scalar and diagonal BEKK models. Diagonal BEKK was estimated only in one paper, but without any explanation regarding statistical validity. The diagonal BEKK model was almost certainly estimated to overcome the "curse of dimensionality" regarding convergence in estimating full BEKK. This raises serious questions and reservations about the unstated convergence in estimating full BEKK in 9 of the 11 published papers. 


\begin{tabular}{|c|c|c|c|c|c|c|}
\hline \multicolumn{7}{|c|}{$\begin{array}{c}\text { Table 1A } \\
\text { Summary of Literature on Volatility Between Energy and Agricultural Markets using BEKK and } \\
\text { DCC }\end{array}$} \\
\hline Author(s) & Journals & Countries & $\begin{array}{l}\text { Energy } \\
\text { commodities }\end{array}$ & $\begin{array}{l}\text { Agricultural } \\
\text { commodities }\end{array}$ & $\begin{array}{l}\text { Sample } \\
\text { periods }\end{array}$ & Prices \\
\hline Algieri (2014) & $\begin{array}{l}\text { Energy } \\
\text { Policy }\end{array}$ & $\begin{array}{l}\text { USA, } \\
\text { France }\end{array}$ & $\begin{array}{l}\text { Ethanol, } \\
\text { crude oil, } \\
\text { biodiesel }\end{array}$ & $\begin{array}{l}\text { Corn, } \\
\text { rapeseed, } \\
\text { soybeans, } \\
\text { soybean oil, } \\
\text { sugar, wheat }\end{array}$ & $2005-2013$ & Futures \\
\hline $\begin{array}{l}\text { Du and } \\
\text { McPhail } \\
\text { (2012) }\end{array}$ & $\begin{array}{l}\text { Energy } \\
\text { Journal }\end{array}$ & USA & $\begin{array}{l}\text { Ethanol, } \\
\text { gasoline, light } \\
\text { crude oil }\end{array}$ & Corn & $\begin{array}{l}2005.3 .25- \\
2011.3 .25\end{array}$ & Futures \\
\hline $\begin{array}{l}\text { Gardebroek } \\
\text { and } \\
\text { Hemandez } \\
(2013)\end{array}$ & $\begin{array}{l}\text { Energy } \\
\text { Economics }\end{array}$ & USA & $\begin{array}{l}\text { Crude oil, } \\
\text { ethanol }\end{array}$ & Corn & $1997-2011$ & Spot \\
\hline $\begin{array}{l}\text { Mensi, } \\
\text { Hammoudeh, } \\
\text { Nguyen and } \\
\text { Yoon (2014) }\end{array}$ & $\begin{array}{l}\text { Energy } \\
\text { Economics }\end{array}$ & $\begin{array}{l}\text { USA, } \\
\text { EU }\end{array}$ & $\begin{array}{l}\text { Oil, } \\
\text { gasoline, } \\
\text { heating oil }\end{array}$ & $\begin{array}{l}\text { Barley, } \\
\text { corn, } \\
\text { sorghum, } \\
\text { wheat }\end{array}$ & $2000-2013$ & Spot \\
\hline Serra (2011) & $\begin{array}{l}\text { Energy } \\
\text { Economics }\end{array}$ & $\begin{array}{l}\text { International, } \\
\text { Brazil }\end{array}$ & $\begin{array}{l}\text { Crude oil, } \\
\text { ethanol }\end{array}$ & Sugar & $\begin{array}{l}2000.7- \\
2009.11\end{array}$ & Spot \\
\hline $\begin{array}{l}\text { Serra and Gil } \\
\text { (2013) }\end{array}$ & $\begin{array}{l}\text { European } \\
\text { Review of } \\
\text { Agricultural } \\
\text { Economics }\end{array}$ & USA & Ethanol & Corn & $\begin{array}{l}1990.1- \\
2010.12\end{array}$ & Nominal \\
\hline $\begin{array}{l}\text { Serra, } \\
\text { Zilberman } \\
\text { and Gil } \\
(2011)\end{array}$ & $\begin{array}{l}\text { European } \\
\text { Review of } \\
\text { Agricultural } \\
\text { Economics }\end{array}$ & $\begin{array}{l}\text { USA, } \\
\text { Brazil }\end{array}$ & $\begin{array}{l}\text { Crude oil, } \\
\text { ethanol }\end{array}$ & Sugar & $\begin{array}{l}2000.7- \\
2008.2\end{array}$ & Spot \\
\hline $\begin{array}{l}\text { Trujillo- } \\
\text { Barrera, } \\
\text { Mallory and } \\
\text { Garcia (2012) }\end{array}$ & $\begin{array}{l}\text { Journal of } \\
\text { Agricultural } \\
\text { and Resource } \\
\text { Economics }\end{array}$ & USA & $\begin{array}{l}\text { Crude oil, } \\
\text { ethanol }\end{array}$ & Corn & $2006-2011$ & Futures \\
\hline $\begin{array}{l}\text { Wu, Guan and } \\
\text { Myers (2011) }\end{array}$ & $\begin{array}{l}\text { Journal of } \\
\text { Futures } \\
\text { Markets }\end{array}$ & USA & Crude oil & Corn & 1992-2009 & $\begin{array}{l}\text { Spot, } \\
\text { futures }\end{array}$ \\
\hline $\begin{array}{l}\text { Wu and } \mathrm{Li} \\
(2013)\end{array}$ & $\begin{array}{l}\text { Energy } \\
\text { Policy }\end{array}$ & China & $\begin{array}{l}\text { Crude oil, } \\
\text { fuel ethanol }\end{array}$ & Corn & $2003-2012$ & $\begin{array}{l}\text { Spot, } \\
\text { index }\end{array}$ \\
\hline $\begin{array}{l}\text { Zhang, Lohr, } \\
\text { Escalante and } \\
\text { Wetzstein } \\
(2009)\end{array}$ & Energies & USA & $\begin{array}{l}\text { Ethanol, } \\
\text { gasoline, } \\
\text { oil }\end{array}$ & $\begin{array}{l}\text { Corn, } \\
\text { soybean }\end{array}$ & $\begin{array}{l}1989.3- \\
2007.12\end{array}$ & Spot \\
\hline
\end{tabular}




\begin{tabular}{|c|c|c|c|c|c|c|}
\hline \multicolumn{7}{|c|}{$\begin{array}{c}\text { Table 1B } \\
\text { Summary of Literature on Volatility Between Energy and }\end{array}$} \\
\hline Author(s) & $\begin{array}{l}\text { Data } \\
\text { frequency }\end{array}$ & Data sources & $\begin{array}{l}\text { Software } \\
\text { packages }\end{array}$ & $\begin{array}{l}\text { Multivariate } \\
\text { models }\end{array}$ & $\begin{array}{l}\text { Univariate } \\
\text { models }\end{array}$ & Spillovers \\
\hline Algieri (2014) & Daily & Bloomberg & Unstated & $\begin{array}{l}\text { Diagonal } \\
\text { BEKK }\end{array}$ & $\begin{array}{l}\text { GARCH, } \\
\text { EGARCH }\end{array}$ & $\begin{array}{l}\text { Partial } \\
\text { covolatility }\end{array}$ \\
\hline $\begin{array}{l}\text { Du and McPhail } \\
\text { (2012) }\end{array}$ & Daily & $\begin{array}{l}\text { CME (corn, ethanol, } \\
\text { gasoline, light crude } \\
\text { oil), NYMEX } \\
\text { (gasoline) }\end{array}$ & Unstated & Scalar DCC & GARCH & $\begin{array}{l}\text { Partial } \\
\text { covolatility }\end{array}$ \\
\hline $\begin{array}{l}\text { Gardebroek and } \\
\text { Hemandez } \\
\text { (2013) }\end{array}$ & Weekly & $\begin{array}{l}\text { EIA (oil), } \quad \text { CBOT } \\
\text { (ethanol), FAO (corn) }\end{array}$ & Unstated & $\begin{array}{l}\text { Full BEKK, } \\
\text { scalar DCC }\end{array}$ & GARCH & $\begin{array}{l}\text { Full volatility, } \\
\text { Full } \\
\text { covolatility, } \\
\text { Partial } \\
\text { covolatility }\end{array}$ \\
\hline $\begin{array}{l}\text { Mensi, } \\
\text { Hammoudeh, } \\
\text { Nguyen and } \\
\text { Yoon (2014) }\end{array}$ & Daily & $\begin{array}{l}\text { EIA (energy), IGC } \\
\text { (cereal) }\end{array}$ & Unstated & $\begin{array}{l}\text { Full BEKK, } \\
\text { scalar DCC }\end{array}$ & GARCH & $\begin{array}{l}\text { Full volatility, } \\
\text { Full } \\
\text { covolatility, } \\
\text { Partial } \\
\text { covolatility }\end{array}$ \\
\hline Serra (2011) & Weekly & $\begin{array}{l}\text { CEPEA (ethanol, } \\
\text { sugar), EIA } \\
\text { (crude oil) }\end{array}$ & Unstated & Full BEKK & $\begin{array}{l}\text { Semi- } \\
\text { parametric } \\
\text { GARCH }\end{array}$ & $\begin{array}{l}\text { Full volatility, } \\
\text { Full } \\
\text { covolatility, } \\
\text { Partial } \\
\text { covolatility }\end{array}$ \\
\hline $\begin{array}{l}\text { Serra and Gil } \\
\text { (2013) }\end{array}$ & Monthly & $\begin{array}{l}\text { Nebraska } \\
\text { Government } \\
\text { (ethanol), NASS } \\
\text { (corn) }\end{array}$ & Unstated & Full BEKK & GARCH & $\begin{array}{l}\text { Full volatility, } \\
\text { Full } \\
\text { covolatility, } \\
\text { Partial } \\
\text { covolatility }\end{array}$ \\
\hline $\begin{array}{l}\text { Serra, } \\
\text { Zilberman } \\
\text { and Gil (2011) }\end{array}$ & Weekly & $\begin{array}{l}\text { Center for Advanced } \\
\text { Studies on Applied } \\
\text { Economics (ethanol, } \\
\text { sugar), EIA (crude } \\
\text { oil) }\end{array}$ & $\begin{array}{l}\text { WinRATS } \\
\text { (v. } 6.30)\end{array}$ & Full BEKK & GARCH & $\begin{array}{l}\text { Full volatility, } \\
\text { Full } \\
\text { covolatility, } \\
\text { Partial } \\
\text { covolatility }\end{array}$ \\
\hline $\begin{array}{l}\text { Trujillo- } \\
\text { Barrera, } \\
\text { Mallory and } \\
\text { Garcia (2012) }\end{array}$ & Weekly & $\begin{array}{l}\text { NYMEX (WTI), } \\
\text { CBOT (ethanol, corn) }\end{array}$ & Unstated & Full BEKK & $\begin{array}{l}\text { Threshold } \\
\text { GARCH }\end{array}$ & $\begin{array}{l}\text { Full volatility, } \\
\text { Full } \\
\text { covolatility, } \\
\text { Partial } \\
\text { covolatility }\end{array}$ \\
\hline $\begin{array}{l}\text { Wu, Guan and } \\
\text { Myers (2011) }\end{array}$ & Weekly & $\begin{array}{l}\text { USDA (corn cash), } \\
\text { CBOT (corn futures), } \\
\text { NYMEX (crude oil) }\end{array}$ & Unstated & Full BEKK & $\begin{array}{l}\text { Threshold } \\
\text { GARCH }\end{array}$ & $\begin{array}{l}\text { Full volatility, } \\
\text { Full } \\
\text { covolatility, } \\
\text { Partial } \\
\text { covolatility }\end{array}$ \\
\hline $\begin{array}{l}\text { Wu and } \mathrm{Li} \\
(2013)\end{array}$ & Weekly & $\begin{array}{l}\text { National Bureau of } \\
\text { Statistics of China }\end{array}$ & Unstated & Full BEKK & EGARCH & $\begin{array}{l}\text { Full volatility, } \\
\text { Full } \\
\text { covolatility, } \\
\text { Partial } \\
\text { covolatility }\end{array}$ \\
\hline $\begin{array}{l}\text { Zhang, Lohr, } \\
\text { Escalante and } \\
\text { Wetzstein } \\
(2009)\end{array}$ & Weekly & $\begin{array}{l}\text { Ethanol \& Biodiesel } \\
\text { News (ethanol), EIA } \\
\text { (gasoline, oil,), } \\
\text { USDA (corn, } \\
\text { soybean) }\end{array}$ & Unstated & Full BEKK & GARCH & $\begin{array}{l}\text { Full volatility, } \\
\text { Full } \\
\text { covolatility, } \\
\text { Partial } \\
\text { covolatility }\end{array}$ \\
\hline
\end{tabular}




\begin{tabular}{|c|c|c|c|c|c|}
\hline \multicolumn{6}{|c|}{$\begin{array}{c}\text { Table 1C } \\
\text { Summary of Literature on Volatility Between Energy and Agricultural Markets using BEKK and DCC }\end{array}$} \\
\hline Author(s) & $\begin{array}{l}\text { Analytical } \\
\text { properties } \\
\text { of models }\end{array}$ & $\begin{array}{l}\text { Statistical } \\
\text { properties } \\
\text { of models }\end{array}$ & $\begin{array}{l}\text { Purported } \\
\text { hypothesis } \\
\text { testing }\end{array}$ & $\begin{array}{l}\text { Purported } \\
\text { significance } \\
\text { of estimates }\end{array}$ & $\begin{array}{l}\text { Overall } \\
\text { Assessment }\end{array}$ \\
\hline Algieri (2014) & $\begin{array}{l}\text { Not } \\
\text { addressed }\end{array}$ & $\begin{array}{l}\text { Not } \\
\text { addressed }\end{array}$ & $\begin{array}{l}\text { Ljung-Box Q, } \\
\text { normality, long } \\
\text { memory }\end{array}$ & Yes & Questionable \\
\hline $\begin{array}{l}\text { Du and } \\
\text { McPhail } \\
\text { (2012) }\end{array}$ & $\begin{array}{l}\text { Not } \\
\text { addressed }\end{array}$ & $\begin{array}{l}\text { Not } \\
\text { addressed }\end{array}$ & $\begin{array}{l}\text { Unit root, } \\
\text { cointegration }\end{array}$ & Yes & Questionable \\
\hline $\begin{array}{l}\text { Gardebroek and } \\
\text { Hemandez } \\
\text { (2013) }\end{array}$ & $\begin{array}{l}\alpha+\beta<1 \\
\text { for GARCH }\end{array}$ & $\begin{array}{l}\text { Not } \\
\text { addressed }\end{array}$ & $\begin{array}{l}\text { Ljung-Box Q, } \\
\text { unit root }\end{array}$ & Yes & Questionable \\
\hline $\begin{array}{l}\text { Mensi, } \\
\text { Hammoudeh, } \\
\text { Nguyen and } \\
\text { Yoon (2014) }\end{array}$ & $\begin{array}{l}\text { Not } \\
\text { addressed }\end{array}$ & $\begin{array}{l}\text { Not } \\
\text { addressed }\end{array}$ & $\begin{array}{l}\text { Normality, } \\
\text { unit root, } \\
\text { causality }\end{array}$ & Yes & Questionable \\
\hline Serra (2011) & $\begin{array}{l}\text { Not } \\
\text { addressed }\end{array}$ & $\begin{array}{l}\text { Not } \\
\text { addressed }\end{array}$ & $\begin{array}{l}\text { Unit root, } \\
\text { cointegration }\end{array}$ & Yes & Questionable \\
\hline $\begin{array}{l}\text { Serra and Gil } \\
\text { (2013) }\end{array}$ & $\begin{array}{l}\text { Not } \\
\text { addressed }\end{array}$ & $\begin{array}{l}\text { Not } \\
\text { addressed }\end{array}$ & None & Yes & Questionable \\
\hline $\begin{array}{l}\text { Serra, } \\
\text { Zilberman } \\
\text { and Gil (2011) }\end{array}$ & $\begin{array}{l}\text { Not } \\
\text { addressed }\end{array}$ & $\begin{array}{l}\text { Not } \\
\text { addressed }\end{array}$ & $\begin{array}{l}\text { Unit root, } \\
\text { cointegration }\end{array}$ & Yes & Questionable \\
\hline $\begin{array}{l}\text { Trujillo- Barrera } \\
\text {, Mallory and } \\
\text { Garcia (2012) }\end{array}$ & $\begin{array}{l}\text { Not } \\
\text { addressed }\end{array}$ & $\begin{array}{l}\text { Not } \\
\text { addressed }\end{array}$ & $\begin{array}{l}\text { Unit root, } \\
\text { cointegration }\end{array}$ & Yes & Questionable \\
\hline $\begin{array}{l}\text { Wu, Guan and } \\
\text { Myers (2011) }\end{array}$ & $\begin{array}{l}\text { Not } \\
\text { addressed }\end{array}$ & $\begin{array}{l}\text { Not } \\
\text { addressed }\end{array}$ & $\begin{array}{l}\text { Normality, unit } \\
\text { root, } \\
\text { cointegration }\end{array}$ & Yes & Questionable \\
\hline $\begin{array}{l}\text { Wu and } \mathrm{Li} \\
\text { (2013) }\end{array}$ & $\begin{array}{l}\text { Incorrect } \\
\text { discussion of } \\
\text { leverage } \\
\text { effect for } \\
\text { EGARCH }\end{array}$ & $\begin{array}{l}\text { Not } \\
\text { addressed }\end{array}$ & $\begin{array}{l}\text { Normality, } \\
\text { unit root, } \\
\text { causality }\end{array}$ & Yes & Questionable \\
\hline $\begin{array}{l}\text { Zhang, Lohr, } \\
\text { Escalante and } \\
\text { Wetzstein } \\
(2009)\end{array}$ & $\begin{array}{l}\text { Not } \\
\text { addressed }\end{array}$ & $\begin{array}{l}\text { Not } \\
\text { addressed }\end{array}$ & $\begin{array}{l}\text { Unit root, } \\
\text { cointegration, } \\
\text { causality }\end{array}$ & Yes & Questionable \\
\hline
\end{tabular}

